\title{
John Hansen, MD
}

\section{HLA Transplant Pioneer and Teacher, May 1, 1943 to July 31, 2019}

\author{
Robert Peter Gale (i) ${ }^{1}$
}

Received: 12 September 2019 / Revised: 16 September 2019 / Accepted: 19 September 2019 / Published online: 30 September 2019 C Springer Nature Limited 2019

Effie Petersdorf and Paul Martin wrote the accompanying obituary. I add this personal note.

I met John Hansen more than 50 years ago when he was working at Memorial Sloan-Kettering Cancer Centre (MSKCC) in New York with Prof. Robert Good. Good was a towering figure in modern immunology who described B- and T-cells in humans along with Profs. Max Cooper and Jacques Miller (winners of this year's Lasker Award; Good won it in 1970) but came to a miserable end (read The Painted Mouse). Good was recruited there from the University of Minnesota by Lawrence Rockefeller, head of the MSKCC Board. John came to New York from Minnesota with Prof. Good, where, in 1968, Good performed one of the first successful bone marrow transplants in a child with sex-linked severe combined immune deficiency, a landmark often overlooked. This was at the time of the first wave of enthusiasm for cancer immune therapy.

Rockefeller was quite keen on Good and gave him extraordinary resources. Good lived on the top floor of the main MSKCC building (now 20 offices) and would arrange evening meeting and receptions on a lovely balcony overlooking the Upper East Side and East River, where we would discuss recent scientific advances. Good would arrange weekend meetings at the Rockefeller Pocantico in Westchester Hills, where we had a marvelous time discussing immunology in a casual, elegant setting. The wine was not bad either. John was a very active participant in these soirees, especially in tennis matches and in fireside singing lead by Prof. Richard Gatti, an immunologist who was also a professional pianist.

John left MSKCC in 1977 to join Prof. Don Thomas and colleagues in Seattle, where I met him during the early years of the UCLA transplant programme. Interestingly, when I first visited Seattle in 1974 and asked where the HLA typing for the transplant patients was being done, I was told by Prof. Paul Teraski that it was at UCLA. John changed all that! John's Seattle colleagues have detailed his enormous contributions to haematopoietic cell transplantation and to our understanding of the HLA system.

John was the most sincere, straightforward, lovely person you could ever hope to meet. As proof, I offer the observation he was one of the few HLA experts respected and liked by Prof. Jon van Rood. That's saying a lot.
Robert Peter Gale

robertpetergale@gmail.com

1 http://orcid.org/0000-0000-0000-0000 